\title{
Effect of dietary fatty acids on incorporation of long chain polyunsaturated fatty acids and conjugated linoleic acid in lamb, beef and pork meat: a review
}

\author{
K. Raes*, S. De Smet, D. Demeyer \\ Department of Animal Production, Faculty of Agricultural and Applied Biological Sciences, Ghent University, \\ Proefhoevestraat 10, 9090 Melle, Belgium
}

Received 12 December 2002; received in revised form 21 August 2003; accepted 1 September 2003

\begin{abstract}
Inspired by the health conscious consumer, several studies in meat producing domesticated animals have been completed that have aimed at increasing the polyunsaturated fatty acid content, and in particular the n-3 or $\omega-3$ long chain fatty acids, as well as the conjugated linoleic acid (CLA) content in intramuscular fat of beef, lamb and pork meat. Increasing the $n-3$ content in animal meats can be achieved by including fish oil/fish meal in the diet (i.e. rich in eicosapentaenoic acid (EPA) and docosahexaenoic acid (DHA)), linseed (oil) and/or forages (i.e. rich in linolenic acid (LNA)). Diets rich in LNA result in an increased level of LNA, EPA and docosapentaenoic acid (DPA) in the meat, while in most cases no effect on intramuscular DHA level was observed. Increasing DHA contents in meat was mainly achieved when fish oil/fish meal was included in the animals diet. In most studies, an increased n-3 content in the intramuscular fat was accompanied with a decreased $\mathrm{n}-6$ deposition, mainly due to a lower $\mathrm{n}-6$ dietary supply between the treatments. This resulted in a more favourable $n-6 / n-3$ ratio in the meat while the polyunsaturated fatty acid/saturated fatty acid $(\mathrm{P} / \mathrm{S})$ ratio was less affected.

Attempts to increase the intramuscular c9t11CLA content was accomplished by feeding ruminants n-3 rich diets (linseed either or not in combination with grass (silage)), fish oil or high concentrate diets rich in linoleic acid (LA). The c9t11CLA content in beef and lamb meat varied between 0.2 and $1.0 \mathrm{~g} / 100 \mathrm{~g}$ of total fatty acids and was not increased to a high extent by nutri-
\end{abstract}

Abbreviations: ARA, arachidonic acid; CLA, conjugated linoleic acid; DHA, docosahexaenoic acid; DPA, docasapentaenoic acid; EPA, eicosapentaenoic acid; LA, linoleic acid; LNA, linolenic acid; MUFA, monounsaturated fatty acids; PUFA, polyunsaturated fatty acids; SFA, saturated fatty acids

* Corresponding author. Tel.: +32-9-264-9004; fax: +32-9-264-9099.

E-mail address: katleen.raes@ugent.be (K. Raes). 
tional factors. In contrast, including CLA-oils consisting of several CLA isomers in the diet of monogastrics markedly increased the intramuscular CLA content.

(C) 2003 Elsevier B.V. All rights reserved.

Keywords: Conjugated linoleic acid; Intramuscular fat; Meat; n-6/n-3 ratio; Polyunsaturated fatty acids

\section{Introduction}

The fatty acid composition of meat has long been studied but still receives a lot of attention in research because of its implications for human health. Besides a lower total fat intake, human nutritionists are recommending a higher intake of polyunsaturated fatty acids (PUFA), and especially of $n-3$ or $\omega-3$ fatty acids at the expense of $n-6$ or $\omega-6$ fatty acids (e.g. Department of Health, 1994; Voedingsaanbevelingen voor België, 2000). Numerous animal feeding trials have been carried out using different species and breeds aiming at bringing the polyunsaturated fatty acid/saturated fatty acid $(\mathrm{P} / \mathrm{S})$ ratio of meat closer to the recommended value $(>0.7)$, as well as for the $n-6 / n-3$ ratio $(<5)$. Besides the beneficial effects of PUFA for human health (see recent reviews of Connor, 2000; Williams, 2000), the conjugated linoleic acid (CLA) isomers, in particular c9t11CLA and t10c12CLA, have received much attention for their health promoting effects (see recent reviews of Jahreis et al., 2000; Pariza et al., 2000, 2001; Roche et al., 2001).

In the following text, emphasis is laid on the effects of nutrition on the intramuscular fatty acid composition of lamb, beef and pork meat only. This restriction in the data has been chosen since intramuscular fat is irreversibly connected with meat and it cannot be removed before human consumption, as is the case for visible fat, such as subcutaneous fat and backfat. In addition, given the more polyunsaturated fatty acid composition of intramuscular fat compared to removable depot fats, the relevance of intramuscular fat for the intake of long chain PUFA may be larger than expected at first sight. In this respect intramuscular fat may influence human health. On the other hand, the major fat intake from meat products by humans in western societies probably originates from backfat of pigs which is present in many processed meat products. This is in contrast with subcutaneous fat from ruminants, which is generally not or much less consumed by humans. No data are available to our knowledge on the contribution of intramuscular and removable animal fats separately to total fatty acid intake.

Several reviews have been published covering studies describing manipulation of the fatty acid composition of animal meat (Nürnberg et al., 1998; Demeyer and Doreau, 1999; Jakobsen, 1999; Wood et al., 1999), but paying less attention to long chain PUFA. Therefore, it was chosen to incorporate only these, mainly refereed, studies describing the intramuscular fat composition in particular the long chain n-3 or $\omega-3$ (linolenic acid (LNA) C18:3n-3; eicosapentaenoic acid (EPA) C20:5n-3; docosapentaenoic acid (DPA) C22:5n-3 and docosahexaenoic acid (DHA) C22:6n-3) and the long chain n-6 or $\omega-6$ fatty acids (linoleic acid (LA) C18:2n-6; arachidonic acid (ARA) C20:4n-6 and C22:4n-6) or studies determining CLA isomers (c9t11 or t10c12). Indeed the recent, and rapidly increasing interest, in long chain PUFA and CLA isomers in meat motivated this review. 
All data are presented as $\mathrm{g} / 100 \mathrm{~g}$ of total fatty acids to obtain a better comparison of results originating from studies with large differences in fat content. Therefore, some data had to be recalculated from the original references. When fatty acid composition was expressed on an absolute basis (e.g. mg/100 g meat), data were converted to $\mathrm{g} / 100 \mathrm{~g}$ of total fatty acids taking into account the total fat or fatty acid content. Several references reported fatty acid composition of phospholipid and triacylglycerol fractions separately. Total fatty acid composition was then reconstituted based on the total fatty acid content in these fractions. The P/S ratio was always calculated as $(\mathrm{C} 18: 2 \mathrm{n}-6+\mathrm{C} 18: 3 \mathrm{n}-3) /(\mathrm{C} 14: 0+\mathrm{C} 16: 0+\mathrm{C} 18: 0)$, while the $\mathrm{n}-6 / \mathrm{n}-3$ ratio was calculated as $(\mathrm{C} 18: 2 \mathrm{n}-6+\mathrm{C} 20: 3 \mathrm{n}-6+\mathrm{C} 20: 4 \mathrm{n}-6+\mathrm{C} 22: 4 \mathrm{n}-6) /(\mathrm{C} 18: 3 \mathrm{n}-3$ $+\mathrm{C} 20: 5 n-3+\mathrm{C} 22: 5 n-3+\mathrm{C} 22: 6 n-3)$.

\section{Fatty acid composition of intramuscular fat}

Intramuscular fat refers to the fatty acids present in the intramuscular adipose tissue and in the muscle fibres. The intramuscular adipose tissue is comprised of fat cells, isolated or in clusters, along the fibres and in the interfascicular area and contains mainly triacylglycerols, while the lipids of the fibres are cytosolic droplets of triacylglycerols, phospholipids and cholesterol. The amount of triacylglycerols in the fibres is only a minor part of the total intramuscular triacylglycerols. In the muscle, the phospholipid content is relatively constant and less influenced by species, breed, nutrition, and age. However, the phospholipid content depends on the metabolic fibre type of the muscle. More oxidative muscles contain a higher phospholipid proportion due to the higher amount of mitochondria. Phospholipids are characterised by a high PUFA content (20-50\% of total fatty acids in the phospholipids), mainly represented by long chain fatty acids with 18, 20 and 22 carbons and two to six double bonds. In contrast to phospholipids, the content of triacylglycerols varies widely, between 0.2 and $5 \mathrm{~g} / 100 \mathrm{~g}$ of fresh tissue (Sinclair and O'Dea, 1990; Gandemer, 1999) and is mainly dependent on the fat level, breed and the location of the muscle. The largest part of the triacylglycerol fatty acids consists of saturated fatty acids (SFA) and monounsaturated fatty acids (MUFA), while the PUFA (predominantly LA and LNA) content in triacylglycerols may vary between 2 and $30 \mathrm{~g} / 100 \mathrm{~g}$ of total fatty acids. The PUFA content in the triacylglycerols are mainly influenced by species (2-3 and 7-15\% PUFA in the triacylglycerols of beef and pork respectively, Gandemer, 1999). The intramuscular fatty acid composition of the monogastric animals, and in particular the triacylglycerols are a reflection of the dietary fatty acids, while in ruminants the biohydrogenation in the rumen (i.e. saturation of the dietary unsaturated fatty acids) is responsible for the smaller variations in intramuscular fatty acid composition. Phospholipid composition is less influenced by diet, as they are constituents of cell membranes. Large changes in the fatty acid profile of the cell membranes would alter membrane properties and other physiological functions. Therefore, the PUFA proportion of the phospholipids is strictly controlled by a complex enzymatic system, consisting of desaturases and elongases, responsible for the conversion of both LA and LNA to their long chain metabolites (Fig. 1). These enzymes act both on the n- 6 and n-3 fatty acids but have a preference for the n-3 (Brenner, 1989). In addition, there is competition for incorporation into the phospholipids between n-6 and n-3 fatty acids. Hence, some variation in the n-6 and n-3 content in the phospholipids exists. Differences in 
n-6

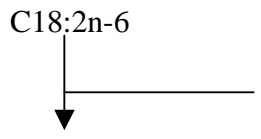

C18:3n-6

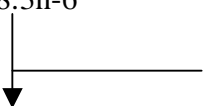

C20:3n-6

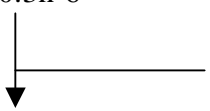

C20:4n-6

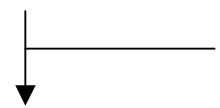

C22:4n-6 n-3

C18:3n-3

$\Delta^{6}$-desaturase

Elongase

$\Delta^{5}$-desaturase

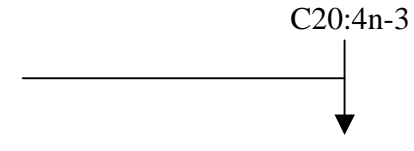

C20:5n-3

Elongase

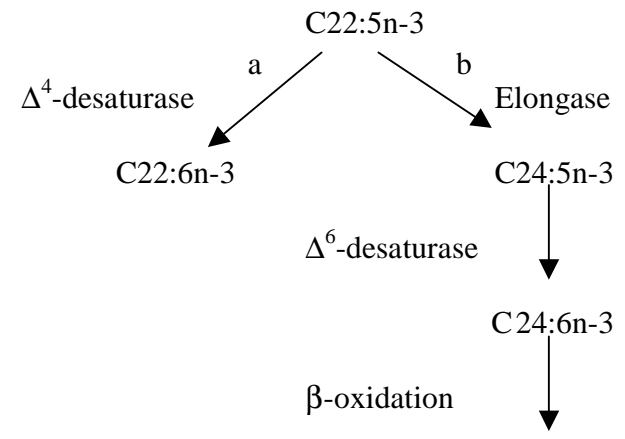

C22:6n-3

Fig. 1. Conversion of C18:2n-6 and C18:3n-3 to their longer chain fatty acid products (a) conventional pathway (Brenner, 1989); (b) pathway proposed by Sprecher et al. (1995).

the ratio of n-6/n-3 fatty acids are dependent on the supply of dietary fatty acids but also on the species. Meat from monogastric animals generally have a higher $n-6 / n-3$ ratio compared to those of ruminants as they are mainly fed with high concentrate grain diets, rich in LA.

The intramuscular FA composition is affected by several genetic and environmental factors, amongst which the dietary supply of fatty acids is generally considered to be the most important. Genetic factors, such as species, breed and sex which are responsible for differences in the fatty acid composition of meat were recently reviewed (De Smet et al., 2003). It was shown that the fat level is inversely related to the P/S ratio, mainly observed in meat from ruminants. Besides genetic effects, the intramuscular fatty acid profile is also affected by nutritional factors, often related to a particular feeding strategy and production system. Several studies have been conducted to modify the fatty acid composition of animal tissues by nutritional means including specific oils or oilseeds, marine products or forages in the animal's diet. 


\section{Increasing the long chain n-3 PUFA in meat}

\subsection{Dietary supplementation of fish oil or fish meal}

Long chain n-3 PUFA, EPA and DHA have a wide range of biological effects, which are believed to be beneficial for human health (Kromhout, 1989; Barlow et al., 1990). These fatty acids are only found in significant amounts in fish oil, fish meal and some algae products (Nettleton, 1991; Givens et al., 2000). Increasing the human intake of n-3 fatty acids is mainly achieved by supplementing the diet with encapsulated fish oil, by increasing the consumption of fish rich in n-3 fatty acids or by enriching the traditionally consumed products like meat and milk with these long chain PUFA. Several trials that fed fish meal or fish oil to lambs, cattle, or pigs have been conducted.

Recently, lambs were fed a fish meal (168 g DM per day) or a barley (179 g DM per day)/fish meal (84 g DM per day) diet (Ponnampalam et al., 2002) and a fish oil or fish oil/sunflower meal diet (Ponnampalam et al., 2001). These four treatments resulted in a two- to four-fold increase in deposition of EPA and DHA in the longissimus, while no effect on LNA deposition was observed compared with the alfalfa and oat based control diet (Table 1). Despite the larger intake of the long chain n-3 fatty acids when fish oil was fed, compared to the fish meal diets, no differences in the intramuscular n-3 content was observed in both studies (Ponnampalam et al., 2001, 2002). Increased EPA and DHA concentrations in intramuscular fat were also observed by Kitessa et al. (2001) feeding a protected tuna oil to lambs compared to a tallow diet (Table 1). Similar results as in these lamb experiments were obtained when fish meal (Mandell et al., 1997) or fish oil (Choi et al., 2000; Scollan et al., 2001) was fed to steers (Table 1).

Only few pig trials have described the effect of fish oil feeding on the intramuscular fatty acid composition (Irie and Sakimoto, 1992; Morgan et al., 1992; Leskanich et al., 1997). Consistent is the increased EPA and DHA deposition in intramuscular fat with the fish oil diets, while the DPA concentration was not affected. These results are similar as those obtained with ruminants and are not surprising as fish oil or fish meal is only rich in EPA and DHA but not in DPA. However, as DPA is formed during elongation of EPA or by retroconversion of DHA (Fig. 1), this observation suggests that these reactions are subjected to an inhibition by the increased concentrations of EPA and DHA in the tissues. It is also possible that the DPA formation and/or incorporation in the tissue is not required in metabolism of mammals.

Feeding fish oil/fish meal markedly increased the total n-3 content, especially by an increase in EPA and DHA concentration in the intramuscular fat due to a higher dietary n-3 supply. This requires that considerable amounts of these fatty acids reach the small intestine. In monogastrics, this is obvious. In ruminants, biohydrogenation of EPA and DHA appears to be limited, even when the fish oil was not protected by technological interventions. Limited biohydrogenation of these long chain PUFA in the rumen has been confirmed in vitro (Ashes et al., 1992; Fievez et al., 2000; Dohme et al., 2003), and its extent depends on the amount of EPA and DHA added to the rumen microorganisms. Increased intramuscular $n-3$ content is accompanied with decreased deposition of n- 6 fatty acids, mainly of LA and ARA, reflecting the lower dietary supply of n-6 fatty acids, mainly LA. Also, ARA has to compete with EPA and DHA for incorporation into phospholipids. However, no trials 
Table 1

Effect of feeding fish oil or fish meal to ruminants on the long chain PUFA of the longissimus ( $\mathrm{g} / 100 \mathrm{~g}$ of total fatty acids) and its effect on the P/S and $\mathrm{n}-6 / \mathrm{n}-3$ ratio

\begin{tabular}{|c|c|c|c|c|c|c|c|c|c|}
\hline & LA & ARA & LNA & EPA & DPA & DHA & $\mathrm{P} / \mathrm{S}$ & $n-6 / n-3$ & Reference \\
\hline \multicolumn{10}{|l|}{ Lamb } \\
\hline Control diet ${ }^{\mathrm{a}}$ & 4.58 & 1.39 & 0.79 & 0.61 & NA & 0.44 & 0.13 & NA & Kitessa et al. (2001) \\
\hline Protected tuna oil ${ }^{\mathrm{a}}$ & 8.27 & 1.64 & 1.06 & 1.81 & NA & 1.01 & 0.23 & NA & Kitessa et al. (2001) \\
\hline Basal diet ${ }^{b}$ & 2.23 & 0.70 & 0.67 & 0.27 & 0.34 & 0.10 & 0.17 & 1.80 & Ponnampalam et al. (2001) \\
\hline $1.5 \%$ Fish oil $^{\mathrm{b}}$ & 2.55 & 0.77 & 0.68 & 0.90 & 0.56 & 0.47 & 0.16 & 1.40 & Ponnampalam et al. (2001) \\
\hline $1.5 \%$ Fish oil $+9 \%$ sunflower meal $^{\mathrm{b}}$ & 2.44 & 0.77 & 0.57 & 0.77 & 0.51 & 0.44 & 0.19 & 1.30 & Ponnampalam et al. (2001) \\
\hline Basal diet ${ }^{b}$ & 3.72 & 1.19 & 0.91 & 0.47 & 0.50 & 0.20 & NA & 2.45 & Ponnampalam et al. (2002) \\
\hline $168 \mathrm{~g} \mathrm{DM}$ fish meal per day ${ }^{\mathrm{b}}$ & 2.97 & 0.72 & 0.83 & 0.93 & 0.65 & 0.47 & NA & 1.29 & Ponnampalam et al. (2002) \\
\hline $\begin{array}{l}179 \text { g DM barley per day }+84 \text { g DM fish } \\
\text { meal per day }{ }^{b}\end{array}$ & 3.56 & 0.78 & 0.89 & 0.90 & 0.63 & 0.48 & NA & 1.50 & Ponnampalam et al. (2002) \\
\hline \multicolumn{10}{|l|}{ Beef } \\
\hline Control diet ${ }^{\mathrm{c}}$ & 3.02 & 0.97 & 0.68 & 0.35 & 0.61 & 0.07 & 0.08 & 2.27 & Choi et al. (2000) \\
\hline $30 \mathrm{~g}$ fish oil $/ \mathrm{kg} \mathrm{DM}+88 \mathrm{~g}$ linseed $/ \mathrm{kg} \mathrm{DM}{ }^{\mathrm{c}}$ & 2.35 & 0.73 & 0.86 & 0.43 & 0.60 & 0.16 & 0.08 & 1.77 & Choi et al. (2000) \\
\hline Control diet ${ }^{\mathrm{d}}$ & 3.3 & 0.70 & 0.40 & 0.10 & 0.30 & 0.01 & 0.08 & 5.63 & Mandell et al. (1997) \\
\hline $5 \%$ Fish meal during $168 \mathrm{~d}^{\mathrm{d}}$ & 3.3 & 0.50 & 0.40 & 0.50 & 0.40 & 0.28 & 0.09 & 4.09 & Mandell et al. (1997) \\
\hline $10 \%$ Fish meal during $168 \mathrm{~d}^{\mathrm{d}}$ & 2.40 & 0.30 & 0.40 & 0.70 & 0.40 & 0.26 & 0.06 & 1.72 & Mandell et al. (1997) \\
\hline Control diet ${ }^{\mathrm{c}}$ & 2.32 & 0.65 & 0.58 & 0.30 & 0.57 & 0.07 & 0.06 & 2.13 & Scollan et al. (2001) \\
\hline $30 \mathrm{~g}$ Fish oil $/ \mathrm{kg} \mathrm{DM}+118 \mathrm{~g}$ linseed $/ \mathrm{kg} \mathrm{DM}^{\mathrm{c}}$ & 1.81 & 0.50 & 0.83 & 0.47 & 0.59 & 0.16 & 0.06 & 1.20 & Scollan et al. (2001) \\
\hline $59.6 \mathrm{~g} \mathrm{Fish} \mathrm{oil} / \mathrm{kg} \mathrm{DM}^{\mathrm{c}}$ & 1.43 & 0.32 & 0.61 & 0.55 & 0.55 & 0.12 & 0.04 & 1.04 & Scollan et al. (2001) \\
\hline
\end{tabular}

NA: data not available; ARA: arachidonic acid (C20:4n-6); DHA: docosahexaenonic acid (C22:6n-3); DPA: docosapentaenoic acid (C22:5n-3); EPA: eicosapentaenoic acid (C20:5n-3); LA: linoleic acid (C18:2n-3); LNA: linolenic acid (C18:3n-3).

a The control diet was tallow based.

$\mathrm{b}$ The basal diet contained mainly alfalfa and oat and served also as the control diet.

${ }^{\mathrm{c}}$ The control diet was based on Megalac (palm-oil based high in C16:0).

${ }^{d}$ The control diet was mainly composed of high moisture corn and alfalfa hay. 
have been conducted with an equal dietary supply of n-6 fatty acids in control and fish oil/meal diets, making it difficult to make a clear conclusion on the effect of fish oil/meal supplementation on the n-6 fatty acid incorporation in the intramuscular fat. Although similar effects were observed on the long chain PUFA by fish oil or fish meal feeding, a lack of information of the dietary fatty acid composition makes comparison of studies difficult.

\subsection{The use of vegetable oils}

Rapeseed and canola oil, derived from low-erucic acid rapeseed, contains about 7 and $11 \%$ LNA, respectively, whereas soybean and wheat germ oils have about $7 \%$ LNA (Reeves and Weihrauch, 1979). Other common vegetable oils, such as corn and safflower oil are poor sources of LNA $(<1 \%)$. Nut oils may contain substantial amounts of LNA, the leading example being walnut oil with 10\% LNA (Reeves and Weihrauch, 1979). However, these oils are rarely used in animal feeds. Perilla oil is the richest source of all with a LNA content of about $64 \%$ of total fatty acids, while linseed (flaxseed) oil contains about 53\% LNA. However, the latter is poorly digested when not technologically treated (e.g. by anti-oxidant incorporation) (Tinoco, 1982). High concentrations of unprotected polyunsaturated oils are seldom used in ruminant diets as high levels of dietary fat disturb the rumen environment and rumen processes (Harfoot and Hazlewood, 1988), although a recent study of Fievez et al. (2003) did not demonstrate any negative effect of increasing levels of oil infusion on rumen processes.

Although rapeseed and soybean oil contain substantial amounts of LNA, the n-6/n-3 ratio of these oils are high due to the presence of high amounts of LA. In this respect it was chosen not to discuss these studies (e.g., Miller et al., 1990; Strzetelski et al., 2001; Beaulieu et al., 2002) in detail as the inclusion of these oils have a low impact on increasing the n-3 fatty acid content in intramuscular fat compared with linseed oil.

Fontanillas et al. (1997) conducted a pig feeding trial with animals from 26 to $96 \mathrm{~kg}$ with linseed oil, pomace oil (high in C18:1c9) or hydrogenated oil (high in C18:1t9). As expected, linseed oil markedly increased the LNA contents of the pork meat and resulted in a higher deposition of EPA and DPA in intramuscular fat. However, no differences could be observed in intramuscular DHA content when compared to the other treatments. Compared with other studies which also supplied 26-27\% of LNA by feeding linseed to pigs (Cherian and Sim, 1995), the oil increased levels of LNA in the intramuscular fat much more markedly than linseed (i.e. 10 and 2-3\% LNA in the intramuscular fat, respectively). This difference in response is probably due to differences in digestion and absorption of the fat sources. Triacylglycerols, the predominant lipid structure in the linseed oil, are well digested by mammals (Nelson and Ackman, 1988) while the oil in linseed, embedded in a complex structure, is not readily accessible to digestive enzymes.

Rey et al. (2001) fed pigs a $0.5 \%$ linseed oil diet, in combination with $1.5 \%$ olive oil or sunflower oil, respectively, for 42 days and compared it with the effect of olive or sunflower oil. Including $0.5 \%$ linseed oil was sufficient to modify the intramuscular fatty acid composition towards a higher total n-3 content and of all individual n-3 fatty acids. An increased DHA content by linseed oil feeding (Rey et al., 2001) contrasts with the study of Fontanillas et al. (1997), who used higher dietary LNA levels but found no effect on the DHA level. 


\subsection{The use of higher plants rich in $n-3$}

Some leafy vegetables have a substantial proportion of LNA. However, because of the low total lipid content of such plants (i.e. mostly $<1 \%$ ), the absolute amount of $n-3$ fatty acids is very small. Grains are normally high in LA resulting in a high $n-6 / n-3$ ratio. One of the exceptions in the higher plants is linseed, which contain a high LNA content (approximately $350 \mathrm{~g}$ fat $/ \mathrm{kg}$ fresh material of which around $56 \%$ of the fatty acids is LNA) and as a consequence a low $\mathrm{n}-6 / \mathrm{n}-3$ ratio.

Some studies (Madsen et al., 1992; Nürnberg et al., 1994; Kracht et al., 1996; Warnants et al., 1996) have investigated the value of rapeseed (meal) to increase the intramuscular n-3 content. However, rapeseed also contains substantial amounts of LA resulting in a $n-6 / n-3$ ratio of 2.5 , much higher than linseed with an $n-6 / n-3$ ratio of 0.30 . Therefore, it has been chosen to discuss only the linseed feeding studies in detail. Indeed, the increase of n-3 fatty acids by rapeseed (meal) feeding was much lower compared to the linseed feeding studies.

Many studies have been completed to evaluate the use of linseed as a possible n-3 source in pig nutrition (Cherian and Sim, 1995; Romans et al., 1995a,b; Ahn et al., 1996; Specht-Overholt et al., 1997; Van Oeckel et al., 1997; Enser et al., 2000; Riley et al., 2000) or in beef production (Choi et al., 2000; Scollan et al., 2001; Raes et al., 2002, 2003b). Linseed inclusion has advantages over the use of linseed oil for technological reasons because of its natural antioxidant content. However, linseed as such cannot be used in animal feeding as the seed coat cannot be penetrated by digestive enzymes. Therefore, to improve accessibility the seeds are broken by treatments, such as crushing, bruising, extrusion or expansion. Another disadvantage of linseed, limiting its inclusion in diets, is the presence of linamarin, an antinutritional compound. In ruminant feeding, linseed may be additionally treated with formaldehyde to reduce protein degradation and fatty acid biohydrogenation in the rumen.

In a study of Choi et al. (2000), Holstein-Friesians and Welsh Black steers were fed a diet containing linseed treated with formaldehyde for 90 days, while Scollan et al. (2001) fed Charolais steers a lightly bruised linseed diet for 120 days (Table 2). In both studies, grass silage was fed as forage in a ratio with concentrate of 60/40, and a diet containing Megalac (a derivative of palm oil high in C16:0) was used as the control group. Similar results were obtained in both studies in that the linseed treatments resulted in an increase of total intramuscular n-3 fatty acids, LNA, EPA and DPA but no difference could be observed in DHA content. In a study using Belgian Blue double-muscled animals, crushed linseed was fed either during the whole experimental period (301 days) or only during the last fattening period (83 days; Raes et al., 2002, 2003b; Table 2). In the latter study, it was demonstrated that the fatty acid composition of the diets in the earlier periods of life are important for formation and incorporation of long chain PUFA (i.e. EPA and DPA) into intramuscular fat, and especially in the phospholipids (Table 2). Raising the LNA content could be achieved rapidly, whereas formation of EPA and DPA due to its desaturation and elongation and the incorporation of the latter into the phospholipids seems to take longer. While the intramuscular EPA and DPA contents were increased to a larger extent in the long term feeding group compared to the short term feeding group, the level of DHA was not altered (Raes et al., 2002, 2003b; Table 2). 
Table 2

Effect of linseed feeding on the intramuscular long chain PUFA content of the longissimus in cattle (g/100 g of total fatty acids)

\begin{tabular}{|c|c|c|c|c|c|c|c|c|c|c|c|c|}
\hline Breed & $\begin{array}{l}\text { Duration } \\
\text { (days) }\end{array}$ & Main fat source & $n$ & LA & ARA & LNA & EPA & DPA & DHA & $\mathrm{P} / \mathrm{S}$ & $n-6 / n-3$ & Reference \\
\hline Holstein-Friesian & 90 & Megalac & 6 & 3.02 & 0.97 & 0.68 & 0.30 & 0.57 & 0.07 & 0.06 & 2.13 & Choi et al. (2000) \\
\hline Holstein-Friesian & 90 & $\begin{array}{l}\text { Formaldehyde treated } \\
\text { linseed }\end{array}$ & 6 & 1.98 & 0.64 & 0.92 & 0.29 & 0.47 & 0.09 & 0.07 & 1.62 & Choi et al. (2000) \\
\hline Welsh-Black & 90 & Megalac & 6 & 3.02 & 0.89 & 0.84 & 0.46 & 0.73 & 0.09 & 0.08 & 1.99 & Choi et al. (2000) \\
\hline Welsh-Black & 90 & $\begin{array}{l}\text { Formaldehyde treated } \\
\text { linseed }\end{array}$ & 6 & 2.81 & 1.53 & 2.81 & 0.66 & 0.82 & 0.11 & 0.09 & 1.26 & Choi et al. (2000) \\
\hline Belgian Blue double-muscled & 83 & Crushed linseed & 8 & 17.8 & 4.02 & 2.63 & 0.85 & 1.55 & 0.13 & 0.58 & 4.57 & Raes et al. (2003b) \\
\hline Belgian Blue double-muscled & 301 & Crushed linseed & 8 & 11.7 & 2.68 & 3.96 & 1.23 & 1.73 & 0.14 & 0.42 & 2.14 & Raes et al. (2003b) \\
\hline Charolais & 120 & Megalac & 8 & 2.32 & 0.65 & 0.58 & 0.30 & 0.57 & 0.07 & 0.04 & 2.13 & Scollan et al. (2001) \\
\hline Charolais & 120 & Lightly bruised linseed & 8 & 1.91 & 0.53 & 1.05 & 0.41 & 0.55 & 0.07 & 0.07 & 1.24 & Scollan et al. (2001) \\
\hline
\end{tabular}

Megalac (palm-oil based high in C16:0) was the main fat source in the control diet. ARA: arachidonic acid (C20:4n-6); DHA: docosahexaenonic acid (C22:6n-3); DPA: docosapentaenoic acid (C22:5n-3); EPA: eicosapentaenoic acid (C20:5n-3); LA: linoleic acid (C18:2n-3); LNA: linolenic acid (C18:3n-3). 
Table 3

Effect of amount and duration of feeding bruised linseed to pigs on the intramuscular long chain fatty acid profile of the longissimus (g/100 g of total fatty acids; data from Riley et al., 2000)

\begin{tabular}{llllllllll}
\hline $\begin{array}{l}\text { Linseed } \\
\text { g/kg feed }\end{array}$ & $\begin{array}{l}\text { Duration } \\
\text { (days) }\end{array}$ & LA & ARA & LNA & EPA & DPA & DHA & $P / S$ & n-6/n-3 \\
\hline 114 & 24 & 14.2 & 2.70 & 2.91 & 0.27 & 0.74 & 0.20 & 0.47 & 3.8 \\
10 & 65 & 13.3 & 2.59 & 1.19 & 0.44 & 0.81 & 0.30 & 0.38 & 5.8 \\
30 & 65 & 12.8 & 1.28 & 1.88 & 0.67 & 0.94 & 0.27 & 0.39 & 3.9 \\
\hline
\end{tabular}

ARA: arachidonic acid (C20:4n-6); DHA: docosahexaenonic acid (C22:6n-3); DPA: docosapentaenoic acid (C22:5n-3); EPA: eicosapentaenoic acid (C20:5n-3); LA: linoleic acid (C18:2n-3); LNA: linolenic acid (C18:3n-3).

These results of Raes et al. (2002, 2003b) confirm earlier work of Riley et al. (2000) who conducted a pig trial with treatments differing in the duration and level of linseed feeding (Table 3). In this study, the long term feeding experiment (65 days for $30 \mathrm{~g}$ linseed/kg feed) resulted in a higher amount of C20 and C22 PUFA compared with the short term feeding trial (24 days for $114 \mathrm{~g}$ linseed/kg feed) despite the lower total amounts of LNA consumed by the long term fed pigs. In this long term experiment, the pigs were younger (initial live weight $46 \mathrm{~kg}$ ) compared to those of the short term trial, thus muscle and fat growth had still to be realised. The long chain metabolites of LNA, EPA and DPA are highly incorporated in muscle phospholipids, of which turnover is slow (Drackley, 2000), and more susceptible to change in the early growth period of the pigs, resulting in a higher effect of the LNA feeding in the long term trials.

Increased amounts of linseed fed to pigs during a fixed period resulted in increased tissue deposition of LNA, EPA and DPA, but the level of DHA was not influenced by linseed feeding (Romans et al., 1995a,b; Ahn et al., 1996; Riley et al., 2000). Only Enser et al. (2000) observed an increased DHA level in intramuscular pork fat by feeding linseed, however, the increase was small $(0.38$ and $0.45 \mathrm{~g} / 100 \mathrm{~g}$ of total fatty acids for the control and linseed fed group, respectively).

In contrast with other studies, Riley et al. (2000) formulated the swine's diets in a long-term study (65 days) to supply the different experimental groups an equal amount of LA, with increasing levels of dietary LNA (Table 3). This resulted in no statistical differences in total or individual n-6 fatty acids deposited in the longissimus, while for other linseed feeding trials with an unequal supply of dietary LA and LNA, an increased intramuscular n-3 content is associated with a decreased n-6 level in pigs (Specht-Overholt et al., 1997; Enser et al., 2000). Similar results to those of Riley et al. (2000) were obtained with Belgian Blue cattle fed diets equal in LA combined with increasing amounts of LNA (Raes et al., 2004).

\subsection{The use of forages}

Lorenz et al. (2002) observed an increase in total n-3 fatty acids (4.5-fold), and in all individual n-3 fatty acids LNA (six-fold), EPA (6.5-fold), DPA (2.3-fold) and DHA (three-fold) in pasture finished bulls compared to concentrate (i.e. no added n-3 source) fed animals. Similar trends were observed by Marmer et al. (1984) using Brangus $\times$ Hereford $\times$ Angus steers raised on pasture or on a high grain diet, by Ender et al. (1997) using Black Pied steers, 
by Itoh et al. (1999) using Simmental steers finished on pasture or on grain, by Nürnberg et al. (2002) using German Holstein and Simmental bulls fed on concentrate or on grass, and by Yang et al. (2002) using pasture and grain-fed Hereford crossbred steers. Finishing cattle on pasture leads to an enrichment in n-3 fatty acids at the expense of n- 6 fatty acids. Similar results were observed in a study with Black Head lambs raised permanently on pasture, or raised on pasture with finishing indoors (Nürnberg et al., 1996), and in a study of Sañudo et al. (2000) that raised lambs in an extensive or intensive system. French et al. (2000) studied effects of decreasing the concentrate proportion in a concentrate-grass based diet using continental crossbred steers. The intramuscular fat of the longissimus linearly increased in n-3 fatty acid content when the amount of concentrate in the diet decreased, while no effect was observed on the n-6 content. Despite the large difference in dietary LA and LNA supply between the treatment groups, these authors only observed an effect of the diet on the intramuscular LNA content. No effect of diet on EPA, LA or ARA was detected, whereas DPA and DHA were not measured. This contrasts with other studies that raised ruminants on pasture or with high amounts of grass silage, where the effect of dietary supply in n-3 and n-6 fatty acids is reflected in the intramuscular fatty acid composition. Scollan et al. (2002a) raised Welsh Black and Simmental steers on grass, or grass plus white or red clover. Including clover decreased the intramuscular content of EPA while the deposition of LA, LNA and ARA were significantly increased. Similar results were reported by Vipond et al. (1993) finishing lambs on swards containing white clover compared to grass finished lambs.

In contrast with ruminants, pigs are generally fed high concentrate diets without forage. However, in relation to the development of organic farming and extensive production systems, several studies were recently completed to investigate the effect of silages in pig diets on the final intramuscular fatty acid composition. Nilzen et al. (2001) observed a higher $\mathrm{n}-3$ content in free range pigs (access to fresh grass + supplemented with a concentrate) compared to indoor fattened pigs fed only a concentrate $(0.93$ and $1.09 \mathrm{~g} / 100 \mathrm{~g}$ of total fatty acids for high concentrate fed and free range pigs, respectively). Johansson et al. (2002) fed a concentrate diet either alone or in combination with red clover silage (10\% of the total energy intake) to pigs. This resulted in a higher level of intramuscular n-3 fatty acids (2.1 and $2.8 \mathrm{~g} / 100 \mathrm{~g}$ of total fatty acids for the control and the red clover silage supplemented pigs, respectively) mainly due to a higher intramuscular content of LNA, EPA and DPA.

\subsection{Effect of the dietary $n-3$ sources on the $n-6 / n-3$ and $P / S$ ratios}

Dietary n-3 source (i.e. fish products, vegetable oils and seeds) does not effect the P/S ratio (Tables 1-3). This is consistent with the statement made by De Smet et al. (2003) that the P/S ratio is mainly influenced by genetics, in particular the overall fat level of the animal, and much less by nutrition. The minor effect of nutrition on the P/S ratio of the meat is particularly important for ruminants as a part of their dietary unsaturated fatty acids are hydrogenated in the rumen, in contrast to monogastrics.

However, the $n-6 / n-3$ ratio is highly influenced by the fatty acid composition of the diet fed to the animals. Including n-3 sources in the diet of the animal increases the total n-3 content, mostly concomitantly with decreased deposition of intramuscular n- 6 fatty acids, as the dietary n-6 supply is lowered, and lowers the n-6/n-3 ratio. Finishing ruminants 


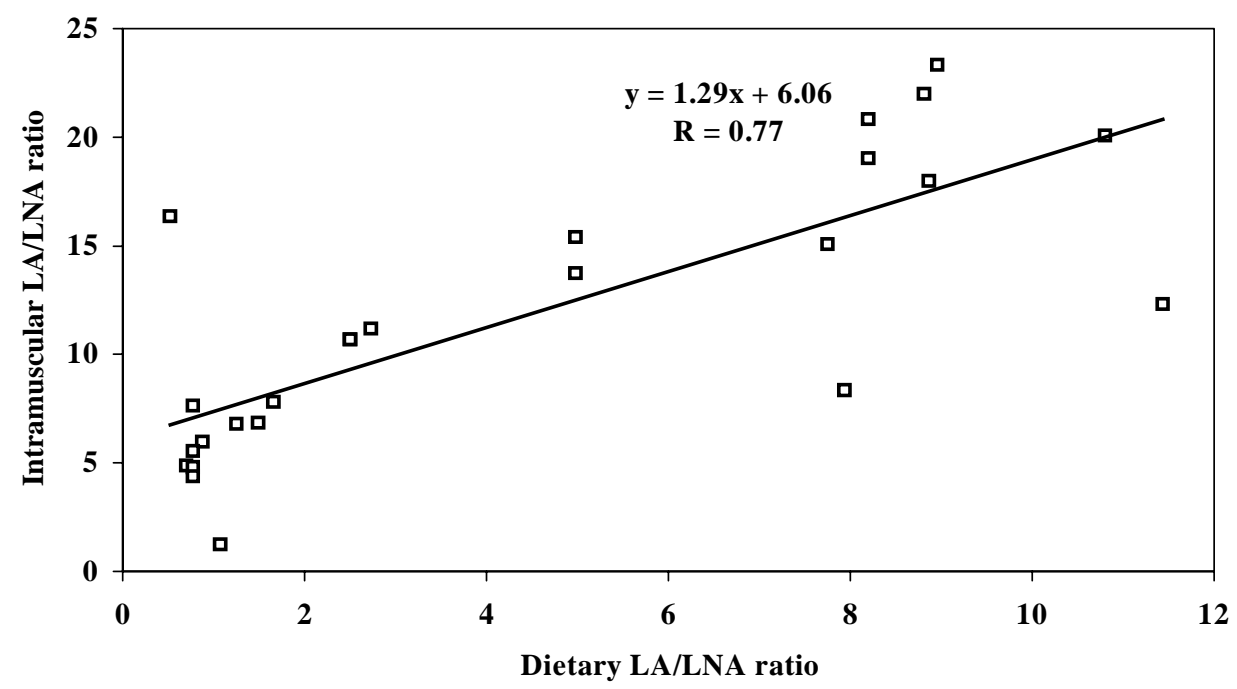

Fig. 2. Relationship between dietary LA/LNA ratio and intramuscular LA/LNA ratio in pork (data obtained from Romans et al., 1995a; Fontanillas et al., 1997; Leskanich et al., 1997; Enser et al., 2000; Matthews et al., 2000; Riley et al., 2000; Johansson et al., 2002).

on pasture can decrease the n-6/n-3 ratio to a value of two or less, while concentrate fed ruminants gave ratios around 6-10 (Marmer et al., 1984; Enser et al., 1998; Choi et al., 2000; Sanudo et al., 2000; Scollan et al., 2001; Lorenz et al., 2002; Nürnberg et al., 2002; Yang et al., 2002). If the ruminants are very lean like Belgian Blue double-muscled bulls, the $\mathrm{n}-6 / \mathrm{n}-3$ ratio of these high concentrate fed animals is close to the nutritional recommended ratios (Raes et al., 2001, 2003a,b, 2004). However, the range of the $n-6 / n-3$ ratio will be more narrow (i.e. between 2.5 and 7) and it probably would be difficult to decrease the ratio to values lower than 2. This is mainly due to the high amounts of LA presents in the phospholipid fraction of lean animals. Both the dietary supply of LA and LNA (or EPA and DHA in marine products) and the dietary ratio LA/LNA, are important for the final intramuscular fatty acid composition. A strong linear relationship exists between dietary LA/LNA and intramuscular LA/LNA (Fig. 2) or intramuscular n-6/n-3 ratio (Fig. 3) in pork meat. The relation between dietary LA/LNA and the intramuscular LA/LNA, and n-6/n-3 ratio in ruminant meat, is less clear due to biohydrogenation of unsaturated fatty acids in the rumen.

\subsection{Conclusive remarks on increased levels of $n-3$ fatty acids by dietary interventions}

Despite the high supply of LNA in diets of meat animals, the increase of intramuscular LNA content and of its metabolites is limited. First, in ruminants high amounts of the dietary LA and LNA are hydrogenated in the rumen. The degree of biohydrogenation of LA and LNA in vivo in ruminants was estimated at 80 and $92 \%$, respectively, by Doreau and Ferlay (1994), lowering the duodenal availability of LNA relatively more than LA compared to 


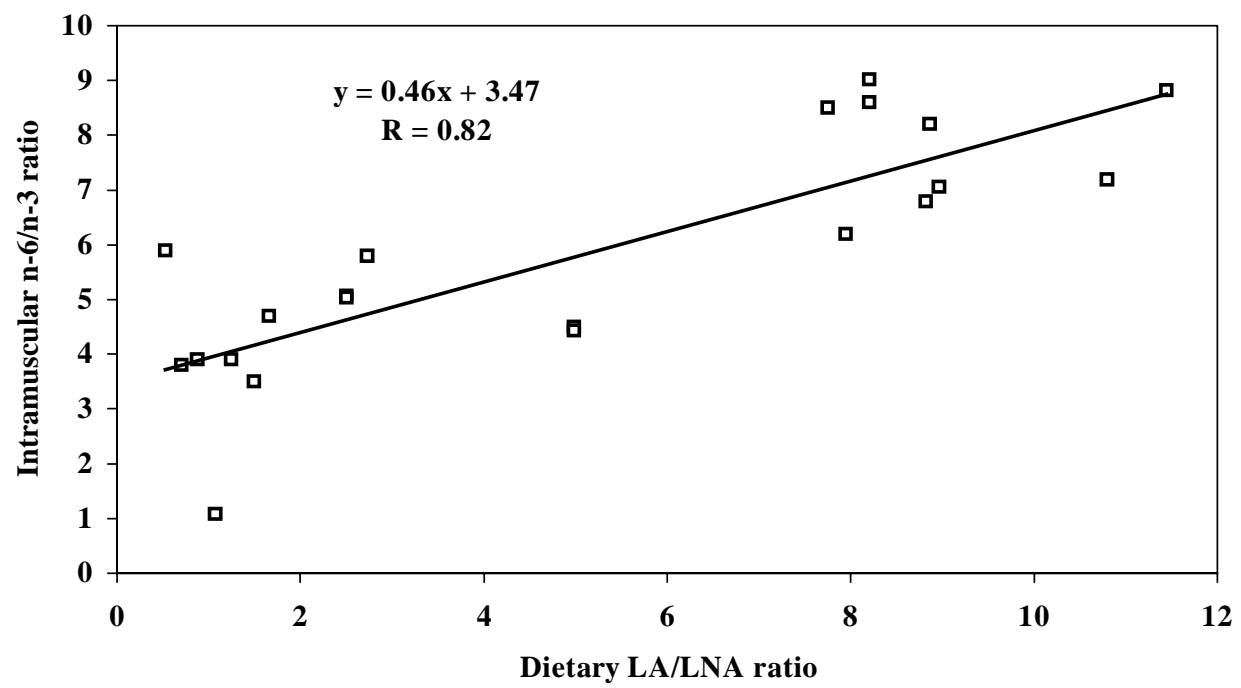

Fig. 3. Relationship between dietary LA/LNA ratio and intramuscular n-6/n-3 ratio in pork (data obtained from Fontanillas et al., 1997; Leskanich et al., 1997; Enser et al., 2000; Matthews et al., 2000; Riley et al., 2000; Johansson et al., 2002).

their dietary levels. Only formaldehyde treatment has been shown to reduce significantly the degree of biohydrogenation (Gulati et al., 1997), and to result in a significant increase in n-3 fatty acids when applied to linseed (Scollan et al., 2002b). Secondly, oxidation rate of fatty acids may differ. Leyton et al. (1987) suggested that LNA has the fastest in vitro rate of oxidation of 6 unsaturated fatty acids and if LNA is preferentially oxidised for energy, which could account for low incorporation rates observed with LNA. Thirdly, after absorption LNA has to compete with LA for incorporation and for desaturation and elongation to its longer chain metabolites in the tissues (Mohrhauer and Holman, 1963).

As stated earlier, the use of vegetable oils or whole grains results in only a limited increase of DHA in muscle tissue. Fish oil or fish meal seems to be the only sources that stimulate deposition of both EPA and DHA to a high extent. It can therefore be concluded that the DHA formation is strictly metabolically regulated and cannot be substantially influenced by diet for both monogastric animals and ruminants, at least when it is not supplied in the diet. The desaturation/elongation chain of n-3 fatty acids seems to block at the level of DPA. Several reasons for this observation can be hypothesised: (1) a low activity of the $\Delta^{4}$-desaturase which convert DPA to DHA; (2) an inhibition or a low activity of the $\Delta^{6}$-desaturase and the $\beta$-oxidation which are responsible for the conversion of DPA to DHA through a more complex route than the step proposed in (1) (Sprecher et al., 1995); (3) an inhibition of the enzymes (desaturase, elongase; $\beta$-oxidation) by other polyunsaturated fatty acids (LA, ARA and LNA); (4) a competition of the long chain polyunsaturated fatty acids (LA, LNA, ARA, EPA, DPA) with DHA to be incorporated into the phospholipids; (5) a production of DHA is confined to tissues requiring this fatty acid, such as the nervous system as proposed by Bauer et al. (1998). 
Although several studies have demonstrated the health benefits of n-3 PUFA on health, e.g. immune status, cardiovascular disease, arthritis (Calder, 1997; Harbige, 1998; Sperling, 1998; Weber and Raederstorff, 2000; Teitelbaum and Walker, 2001), one could question the need for animal products fortified in n-3 fatty acids to human nutrition. The consumption of long chain n-3 fatty acids EPA and DHA is normally originating from the intake of fatty fish (such as salmon, tuna, mackerel and herring). As in Western societies the intake of fatty fish is low and traditional eating habits are difficult to change within a population, the consumption of n-3 fatty acids from terrestrial animal products is mainly limited to the intake of LNA, and a very small part as EPA and DHA. Despite the low amounts of the long chain n-3 fatty acids present in the terrestrial animal products they are of significant importance for many people. Furthermore, the production of fish by aquaculture may increase the amount of n-6 fatty acids at the expense of n-3 fatty acids (Sargent and Tacon, 1999; Van Vliet and Katan, 1990). Therefore, it is advised that feeding strategies are adapted to bring the fatty acid composition of terrestrial animal products more in line with the values proposed by the different nutritional recommendations. Indeed, Weill et al. (2002) has recently shown that the n-6/n-3 ratio in human red blood cells and plasma significantly decreased when humans were having a diet including products from terrestrial animals (meat, milk, eggs) having received a linseed containing diet.

\section{Increasing the conjugated linoleic acid content in meat}

A number of studies have recently been conducted with special emphasis on the amount of CLA in animal products and its effects on human health. The term CLA refers to a group of positional and geometric isomers of octadecaenoic acid with a conjugated double bond system, of which the c9t11 and t10c12 isomers are the most abundant. Both isomers are naturally found in ruminant derived food products (Chin et al., 1992), as ruminants metabolise PUFA in the rumen, i.e. lipolysis and biohydrogenation, in which c9t11CLA and t10c12CLA are formed as intermediates during biohydrogenation of LA (Harfoot and Hazlewood, 1988). Previously it was believed that the CLA produced in the rumen was the most important source of CLA in milk and meat, but recent results strongly suggest that endogenous synthesis of c9t11CLA in the mammary gland (Griinari et al., 2000), or in the subcutaneous or intramuscular fat (Raes et al., 2003c), is the predominant production pathway. Endogenous synthesis of c9t11CLA involves action of the $\Delta^{9}$-desaturase on t11C18:1, which is produced in the rumen. In contrast to c9t11CLA, the production of the $\mathrm{t} 10 \mathrm{c} 12$ isomer in the rumen is the only pathway responsible for the t10c12CLA levels in human edible ruminant products as animal tissues do not possess the desaturase enzyme capable of inserting a C12-double bond into the t10C18:1 molecule. Several studies, aimed at increasing the CLA isomers especially c9t11CLA, both in human edible ruminant and monogastric products are discussed in Section 4.1.

\subsection{Increasing the CLA content in beef and lamb}

Several recent studies have reported that the intramuscular c9t11CLA content of beef (Table 4) and lamb (Haumann and Snell, 2000; Mir et al., 2000b; Ivan et al., 2001) varied 
Table 4

Effect of nutrition on the c9t11CLA content in beef ( $\mathrm{g} / 100 \mathrm{~g}$ of total fatty acids)

\begin{tabular}{|c|c|c|}
\hline Diet & c9t11CLA & Reference \\
\hline High corn concentrate & 0.32 & Beaulieu et al. (2002) \\
\hline High corn concentrate $+5 \%$ soybean oil & 0.36 & Beaulieu et al. (2002) \\
\hline Concentrate $($ megalac $)+$ grass silage & 0.32 & Enser et al. (1999) \\
\hline Concentrate $($ linseed $)+$ grass silage & 0.80 & Enser et al. (1999) \\
\hline Concentrate $($ fish oil $)+$ grass silage & 0.57 & Enser et al. (1999) \\
\hline Concentrate $($ linseed + fish oil $)+$ grass silage & 0.73 & Enser et al. (1999) \\
\hline Barley based concentrate + grass silage ad lib & 0.47 & French et al. (2000) \\
\hline Concentrate + straw & 0.37 & French et al. (2000) \\
\hline $5 \mathrm{~kg}$ concentrate $+6 \mathrm{~kg}$ grass $\mathrm{DM}$ & 0.54 & French et al. (2000) \\
\hline $2.5 \mathrm{~kg}$ concentrate $+12 \mathrm{~kg}$ grass $\mathrm{DM}$ & 0.66 & French et al. (2000) \\
\hline $22 \mathrm{~kg}$ grass $\mathrm{DM}$ & 1.08 & French et al. (2000) \\
\hline Concentrate + maize silage & 0.86 & Fritsche and Fritsche (1998) \\
\hline Concentrate + maize silage & 0.76 & Fritsche and Fritsche (1998) \\
\hline Grain finished & 0.36 & Laborde et al. (2001) \\
\hline Grain finished & 0.35 & Laborde et al. (2001) \\
\hline Concentrate & 0.29 & Lorenz et al. (2002) \\
\hline Pasture & 0.32 & Lorenz et al. (2002) \\
\hline Concentrate & 0.66 & Madron et al. (2002) \\
\hline Concentrate $+127 \mathrm{~g}$ extruded full-fat soybeans/kg DM & 0.69 & Madron et al. (2002) \\
\hline Concentrate $+256 \mathrm{~g}$ extruded full-fat soybeans $/ \mathrm{kg} \mathrm{DM}$ & 0.77 & Madron et al. (2002) \\
\hline Barley-based feedlot $(800 \mathrm{~g} / \mathrm{kg})$ & 0.17 & Mir et al. (2000a) \\
\hline Barley-based feedlot ( $800 \mathrm{~g} / \mathrm{kg})$ & 0.18 & Mir et al. (2000a) \\
\hline Concentrate (n-6 rich) & 0.52 & Nürnberg et al. (2002) \\
\hline Pasture & 0.55 & Nürnberg et al. (2002) \\
\hline Concentrate (n-6 rich) & 0.56 & Nürnberg et al. (2002) \\
\hline Pasture & 0.60 & Nürnberg et al. (2002) \\
\hline Concentrate (n-6 rich) & 0.34 & Raes et al. (2003b) \\
\hline Concentrate (linseed based) + grass silage & 0.59 & Raes et al. (2003b) \\
\hline Concentrate (linseed based) + maize silage & 0.50 & Raes et al. (2003b) \\
\hline Feedlot fed & 0.26 & Rule et al. (2002) \\
\hline Range/pasture fed & 0.41 & Rule et al. (2002) \\
\hline Finished on grass & 0.55 & Scollan et al. (2002a) \\
\hline Finished on grass + red clover & 0.60 & Scollan et al. (2002a) \\
\hline Finished on grass + white clover & 0.63 & Scollan et al. (2002a) \\
\hline Concentrate $(+$ ground linseed $)+$ maize silage & 0.29 & Strzetelski et al. (2001) \\
\hline Concentrate $(+$ rapeseed oil cake $)+$ maize silage & 0.31 & Strzetelski et al. (2001) \\
\hline Concentrate $(+$ soybean oil meal $)+$ maize silage & 0.21 & Strzetelski et al. (2001) \\
\hline Grain finished concentrates & 0.06 & Yang et al. (2002) \\
\hline Pasture finished & 0.22 & Yang et al. (2002) \\
\hline
\end{tabular}

between 0.2 and $1 \mathrm{~g} / 100 \mathrm{~g}$ of total fatty acids. Increased levels were observed when beef cattle or lambs were fed LNA rich sources (linseed or grass; Enser et al., 1999; French et al., 2000; Lorenz et al., 2002; Raes et al., 2002, 2003b; Rule et al., 2002; Scollan et al., 2002a; Strzetelski et al., 2001; Yang et al., 2002), high concentrate diets rich in LA (Ivan et al., 2001; Beaulieu et al., 2002; Madron et al., 2002) or concentrates including fish oil (Enser et al., 1999). Increased c9t11CLA levels as a result of feeding LNA rich sources may not be 
immediately sensible at first sight since c9t11CLA is an intermediate in the hydrogenation pathway of LA. However, since the endogenous production of c9t11CLA should probably be more important than its ruminal production (Griinari et al., 2000; Raes et al., 2003c), increased production of its precursor $11 \mathrm{C} 18: 1$ in the rumen during biohydrogenation of LA or LNA is thought to be responsible for these higher c9t11CLA tissue levels. Surprisingly, feeding fish oils to steers also resulted in increased c9t11CLA deposition in the longissimus (Enser et al., 1999), similar to previously reported for milk (Chilliard et al., 2001). The reason for this is not clear, as no $111 \mathrm{C} 18: 1$ is formed during biohydrogenation of the long chain fish oil fatty acids EPA and DHA. Therefore, it is more likely that EPA and/or DHA are interfering in biohydrogenation of LA and/or LNA or are influencing activity of the $\Delta^{9}$-desaturase.

Separating lipids into triacylglycerols and phospholipids showed that the c9t11CLA isomer is predominantly deposited in the triacylglycerols (Fritsche et al., 2001; Lorenz et al., 2002; Raes et al., 2003b; Scollan et al., 2002a) and, as a consequence, a quantitatively higher c9t11CLA content in beef is associated with a higher intramuscular fat content. Intramuscular levels of t10c12CLA are very low (0.004-0.12 g/100 g of total fatty acids) and only few studies determining the CLA content by simple gas chromatography have reported the intramuscular t10c12 content (Beaulieu et al., 2002; Rule et al., 2002). However, despite the different diets and fat sources used in these experiments with ruminants, levels of c9t11CLA content in beef and lamb are always much lower compared to their content in milk.

Future studies will probably focus on a higher ruminal t11C18:1 production to enhance endogenous formation of c9t11CLA in beef and lamb. It still has to be investigated if production of the precursor, or the activity of the $\Delta^{9}$-desaturase, is the limiting factor for achieving a higher tissue CLA deposition.

\subsection{Increasing the CLA content in pork}

As the many potential health effects of CLA are of considerable interest to human health and the increase in CLA contents in beef and lamb is rather limited, the effects of CLA inclusion into the swine diets have been investigated. Feed-grade CLA has recently come on the commercial market resulting in a higher interest in incorporating CLA into pig feeds for production of fresh meat and meat products with an added value for human health. Feeding these purified CLA may be a more efficient way to increase the meat CLA content due to the minimal hydrogenation of unsaturated fatty acids in the monogastric digestive tract prior to absorption from the small intestine. However, they are chemically produced and consist of a mixture of isomers of which all effects are not well known at this time. Whereas CLA is a natural compound of ruminant products, of which the beneficial health effects could be exploited and communicated to the consumer, it is clear that a similar approach is not obvious for products of pigs fed CLA oils.

Several pig trials have been conducted that fed the animals different commercial CLA sources differing in CLA content and isomer profiles, or by feeding modified tall oil (a by-product of the paper industry that contains CLA). These chemically produced CLA oils comprise a whole range of isomers of which the most abundant are c9t11 and t10c12. Although these studies (O'Quinn et al., 2000; Bee, 2001; Eggert et al., 2001; Ramsay et al., 2001; Thiel-Cooper et al., 2001) involved different breeds, different growing periods, 
different feed composition (as well as in CLA content and isomers, as in total fat content and fatty acid composition), some findings are consistent throughout. For example, incorporation of the c9t11 isomer into intramuscular or subcutaneous fat was always higher that of the $\mathrm{t} 10 \mathrm{c} 12$ isomer, although the dietary level of the $\mathrm{t} 10 \mathrm{c} 12$ isomer was 5-20\% higher than of the c9t11 isomer. Park et al. (1999a) stated that the t10c12 isomer appeared to be metabolised more rapidly than the c9t11 isomer, especially in skeletal muscle, leading to the higher deposition of the c9t11 isomer.

Incorporating CLA into the pig diets resulted in increased deposition of SFA (C14:0, C16:0 and C18:0) and a decrease in MUFA (mainly C18:1). Decreased concentration of MUFA, concomitant with an increase in SFA is due to inhibition of the $\Delta^{9}$ desaturase. MUFA are synthesised by the stearoyl-CoA desaturase enzyme, which catalyses the $\Delta^{9}$-desaturation of fatty acyl-CoA substrates. In vivo and in vitro studies have shown that CLA reduces MUFA levels by reduction of the stearoyl-CoA desaturase activity through suppression of its mRNA expression (Lee et al., 1998; Bretillon et al., 1999). From these experiments, it is difficult to attribute these effects to one of the two main dietary isomers c9t11CLA or t10c12CLA. In liver cells of mice, it has been shown that the t10c12 isomer was responsible for both reducing the enzyme activity as well as the mRNA expression of the desaturase (Lee et al., 1998). It is still unknown if this finding is valid in vivo.

Gläser et al. (2000) fed hydrogenated fat, rich in tC18:1 isomers $(1.79 \mathrm{~g}$ t6-9 C18:1/kg feed and $1.39 \mathrm{~g} \mathrm{t} 10-11 \mathrm{C} 18: 1 / \mathrm{kg}$ feed), resulting in a higher $\mathrm{c} 9 \mathrm{t} 11 \mathrm{CLA}$ content in the adipose tissue of pigs compared to the control diets $(0.44$ and $<0.01 \mathrm{~g}$ c9t11CLA/100 $\mathrm{g}$ of total fatty acids, respectively), but also resulting in a four to eight times higher deposition of tC18:1 isomers. These results suggest that formation of c9t11CLA through the action of the $\Delta^{9}$-desaturase on t11C18:1 also occurs in non-ruminants, such as pigs.

Increasing the content of n-3 fatty acids, simultaneous with administration of CLA in the feed, could result in meat with the health benefits of n-3 and CLA. However, increases in the SFA content, especially increased levels of C14:0 and C16:0, are to be avoided because of the relation to an increased incidence of atherosclerosis in humans (Zock et al., 1994). If CLA isomers possess anti-atherosclerotic activity in humans, as shown in rabbits (Lee et al., 1994), adverse effects of increasing levels of SFA could be neutralised by the CLA isomers. It has been shown by Stangl et al. (1999) that CLA administration by including CLA-oil in the swine diet, may exhibit a rise in the LDL to HDL cholesterol ratio, which should lower the incidence of atherosclerosis.

It is clear that the benefits of feeding CLA rich oils to pigs are not clear and more research is required to evaluate positive effects of CLA compared to the detrimental effects on human health of a higher SFA content in CLA-supplemented pork.

\section{Conclusion}

For both ruminants and monogastrics, fish oil or fish meal seem to be the only effective way to increase the deposition of DHA. While linseed or linseed oil inclusion in the animals diet supplies LNA, the conversion of LNA to its longer chain metabolites EPA and DPA seems to be limited, resulting in only a small increase in the deposition of EPA and DPA in intramuscular fat. Feeding linseed or linseed oil to ruminants and monogastrics seems 
to have no effect on the intramuscular DHA incorporation. An increase of c9t11CLA in lamb or beef meat can be achieved to some extent by feeding strategies. However, much more research about the mechanism of CLA formation is needed to understand better the underlying processes and as a consequence how nutrition can be responsible for an increased CLA incorporation in the intramuscular fat of lambs and cattle. In pigs CLA incorporation can mainly be achieved by the inclusion of CLA rich oils in the swine's diet.

\section{References}

Ahn, D.H., Lutz, S., Sim, J.S., 1996. Effects of dietary $\alpha$-linolenic acid on the fatty acid composition, storage stability and sensory characteristics of pork loin. Meat Sci. 43, 291-299.

Ashes, J.R., Siebert, B.D., Gulati, S.K., Cuthbertson, A.Z., Scott, T.W., 1992. Incorporation of n-3 fatty acids of fish oil into tissue and serum lipids of ruminants. Lipids 27, 629-631.

Barlow, S.M., Young, F.V.K., Duthie, I.F., 1990. Nutritional recommendations for n-3 polyunsaturated fatty acids and the challenge to the food industry. Proc. Nutr. Soc. 49, 13-21.

Bauer, J.E., Dunbar, B.L., Bigley, K.E., 1998. Dietary flaxseed in dogs results in differential transport and metabolism of (n-3) polyunsaturated fatty acids. J. Nutr. 128, 2641S-2644S.

Beaulieu, A.D., Drackley, J.K., Merchen, N.R., 2002. Concentrations of conjugated linoleic acid (cis-9, trans11-octadecadienoic acid) are not increased in tissue lipids of cattle fed a high-concentrate diet supplemented with soybean oil. J. Anim. Sci. 80, 847-861.

Bee, G., 2001. Dietary conjugated linoleic acids affect tissue lipid composition but not de novo lipogenesis in finishing pigs. Anim. Res. 50, 383-390.

Brenner, R.R., 1989. Factors influencing fatty acid chain elongation and desaturation. In: Vergroesen, A.J., Crawford, M. (Eds.), The Role of Fats in Human Nutrition. Academic Press, California, USA, pp. 45-80.

Bretillon, L., Chardigny, J.M., Grégoire, S., Berdeaux, O., Sébédio, J.L., 1999. Effects of conjugated linoleic acid isomers on the hepatic microsomal desaturation activities in vitro. Lipids 34, 965-969.

Calder, P.C., 1997. n-3 polyunsaturated fatty acids and cytokine production in health and disease. Ann. Nutr. Metab. 41, 203-234.

Cherian, G., Sim, J.S., 1995. Dietary $\alpha$-linolenic acid alters the fatty acid composition of lipid classes in swine tissues. J. Agric. Food Chem. 43, 2911-2916.

Chilliard, Y., Ferlay, A., Doreau, M., 2001. Effect of different types of forages, animal fat or marine oils in cow's diet on milk fat secretion and composition, expecially conjugated linoleic acid (CLA) and polyunsaturated fatty acids. Livest. Prod. Sci. 70, 31-48.

Chin, S.F., Liu, W., Storkson, J.M., Ha, Y.L., Pariza, M.W., 1992. Dietary sources of conjugated dienoic isomers of linoleic acid, a newly recognized class of anticarcinogens. J. Food Compos. Anal. 5, 185-197.

Choi, N.J., Enser, M., Wood, J.D., Scollan, N.D., 2000. Effect of breed on the deposition in beef muscle and adipose tissue of dietary n-3 polyunsaturated fatty acids. Anim. Sci. 71, 509-519.

Connor, W.E., 2000. Importance of n-3 fatty acids in health and disease. Am. J. Clin. Nutr. 71, 171S-175S.

De Smet, S., Raes, K., Demeyer, D., 2003. Meat fatty acid composition as affected by genetics. Anim. Res., in press.

Demeyer, D., Doreau, M., 1999. Targets and procedures for altering ruminant meat and milk lipids. Proc. Nutr. Soc. 58, 593-607.

Department of Health, 1994. Nutritional aspects of cardiovasuclar disease. Report on health and social subjects no. 46. H.M. Stationery Office, London.

Dohme, F., Fievez, V.I., Raes, K., Demeyer, D.I., 2003. Increasing levels of two different fish oils lower ruminal biohydrogenation of eicosapentaenoic and docoshexaenoic acid in vitro. Anim. Res. 52, 309-320.

Doreau, M., Ferlay, A., 1994. Digestion and utilisation of fatty acids by ruminants. Anim. Feed Sci. Technol. 45, 379-396.

Drackley, J.K., 2000. Lipid metabolism. In: D’Mello, J.P.F. (Ed.). Farm Animal Metabolism and Nutrition. CAB International, pp. 97-119.

Eggert, J.M., Belury, M.A., Kempa-Steczko, A.K., Mills, S.E., Schinckel, A.P., 2001. Effects of conjugated linoleic acid on the belly firmness and fatty acid composition of genetically lean pigs. J. Anim. Sci. 79, 2866-2872. 
Ender, K., Papstein, H.-J., Nürnberg, K., Wegner, J., 1997. Muscle and fat related characteristics of grazing steers and lambs in extensive systems. In: Proceedings of the EU-Workshop on 'Effect of extensification on animal performances and product quality' on 14-16 May 1997. Melle-Gontrode, Belgium, pp. 229-232.

Enser, M., Hallett, K., Hewitt, B., Fursey, G.A.J., Wood, J.D., Harrington, G., 1998. Fatty acid content and composition of UK beef and lamb muscle in relation to production system and implications for human nutrition. Meat Sci. 49, 329-341.

Enser, M., Scollan, N.D., Choi, N.J., Kurt, E., Hallet, K., Wood, J.D., 1999. Effect of dietary lipid on the content of conjugated linoleic acid (CLA) in beef. Anim. Sci. 69, 143-146.

Enser, M., Richardson, R.I., Wood, J.D., Gill, B.P., Sheard, P.R., 2000. Feeding linseed to increase the n-3 PUFA of pork: fatty acid composition of muscle, adipose tissue, liver and sausages. Meat Sci. 55, 201-212.

Fievez, V., Van Nevel, C., Demeyer, D., 2000. Lipolysis and biohydrogenation of PUFA's from fish oil during in vitro incubations with rumen contents. Proc. Nutr. Soc. 59, 193A.

Fievez, V., Dohme, F., Danneels, M., Raes, K., Demeyer, D., 2003. Fish oils as potent rumen methane inhibitors and associated effects on rumen fermentation in vitro and in vivo. Anim. Feed Sci. Technol. 104, 41-58.

Fontanillas, R., Barroeta, A., Baucells, M.D., Codony, R., 1997. Effect of feeding highly cis-monounsaturated, trans, or n-3 fats on lipid composition of muscle and adipose tissue of pigs. J. Agric. Food Chem. 45, 3070-3075.

French, P., Stanton, C., Lawless, E.G., O’Riordan, E.G., Monahan, F.J., Caffrey, P.J., Moloney, A.P., 2000. Fatty acid composition, including conjugated linoleic acid of intramuscular fat from steers offered grazed grass, grass silage or concentrate-based diets. J. Anim. Sci. 78, 2849-2855.

Fritsche, S., Fritsche, J., 1998. Occurence of conjugated linoleic acid isomers in beef. JAOCS 75, 1449-1450.

Fritsche, S., Rumsey, T.S., Yurawecz, M.P., Ku, Y., Fritsche, J., 2001. Influence of growth promoting implants on fatty acid composition including conjugated linoleic acid isomers in beef fat. Eur. Food Res. Technol. 212, 621-629.

Gandemer, G., 1999. Lipids and meat quality: lipolysis, oxidation, Maillard reaction and flavour. Sci. Ailments 19, 439-458.

Givens, D.I., Cottrill, B.R., Davies, M., Lee, P.A., Mansbridge, R.J., Moss, A.R., 2000. Sources of n-3 polyunsaturated fatty acids additional to fish oil for livestock diets-a review. Nutr. Abstracts Rev., Ser. B, Livestock Feeds Feed. 70, 1-19.

Gläser, K.R., Scheeder, M.R.L., Wenk, C., 2000. Dietary C18:1 trans fatty acids increase conjugated linoleic acid in adipose tissue of pigs. Eur. J. Lipid Sci. Technol. 102, 684-686.

Griinari, J.M., Corl, B.A., Lacy, S.H., Chouinard, P.Y., Nurmela, K.V.V., Bauman, D.E., 2000. Conjugated linoleic acid is synthesised endogenously in lactating dairy cows by $\Delta^{9}$-desaturase. J. Nutr. 130, 2285-2291.

Gulati, S.K., Scott, T.W., Ashes, J.R., 1997. In vitro assessment of fat supplements for ruminants. Anim. Feed Sci. Technol. 64, 127-132.

Harbige, L.S., 1998. Dietary n-6 and n-3 fatty acids in immunity and autoimmune disease. Proc. Nutr. Soc. 57, $555-562$.

Harfoot, C.G., Hazlewood, G.P., 1988. Lipid metabolism in the rumen. In: Hobson, P.N. (Ed.), The Rumen Microbial Ecosystem. Elsevier, USA, pp. 382-426.

Haumann, P., Snell, H., 2000. Einfluss der Haltungsintensität (Stall vs. Magerrasen-Weide) auf die Fleischleistung von Ziegenlämmern verschiedener Genotypen. Part 2. Mitteilung: Fleischqualität und Fettsäurenmunster. Züchtungskunde 72, 308-318.

Irie, M., Sakimoto, M., 1992. Fat characteristics of pigs fed fish oil containing eicosapentaenoic and docosahexaenoic acids. J. Anim. Sci. 70, 470-477.

Itoh, M., Johnson, C.B., Cosgrove, G.P., Muir, P.D., Purchas, R.W., 1999. Intramuscular fatty acid composition of neutral and polar lipids for heavy-weight Angus and Simmental steers finished on pasture or grain. J. Sci. Food Agric. 79, 821-827.

Ivan, M., Mir, P.S., Koenig, K.M., Rode, L.M., Neill, L., Entz, T., Mir, Z., 2001. Effect of dietary sunflower seed oil on rumen protozoa population and tissue concentration of conjugated linoleic acid in sheep. Small Ruminant Res. 41, 215-227.

Jahreis, G., Kraft, J., Tischendorf, F., Schöne, F., von Leffelholz, C., 2000. Conjugated linoleic acids: Physiological effects in animal and man with special regard to body composition. Eur. J. Lipid Sci. Technol. 102, 695-703.

Jakobsen, K., 1999. Dietary modifications of animal fats: status and future perspectives. Fett/Lipid 101, S475S483. 
Johansson, L., Lundstrom, K., Jonsall, A., 2002. Effects of RN genotype and silage feed on fat content and fatty acid composition of fresh and cooked pork loin. Meat Sci. 60, 17-24.

Kitessa, S.M., Gulati, S.K., Ashes, J.R., Scott, T.W., Fleck, E., 2001. Effect of feeding tuna oil supplement protected against hydrogenation in the rumen on growth and n-3 fatty acid content of lamb fat and muscle. Austr. J. Agric. Res. 52, 433-437.

Kracht, W., Jeroch, H., Matzke, W., Nürnberg, K., Ender, K., Schumann, W., 1996. The influence of feeding rapeseed on growth and carcass fat quality of pigs. Fett/Lipid 98, 343-351.

Kromhout, D., 1989. Fish (oil) consumption and coronary heart disease. In: Galli, C., Simopoulos, A.P. (Eds.), Dietary $\omega-3$ and $\omega-6$ fatty acids. Biological effects and nutritional essentiality. Plenum Publishing, New York, USA, pp. 273-282.

Laborde, F.L., Mandell, I.B., Tosh, J.J., Wilton, J.W., Buchanan-Smith, J.G., 2001. Breed effects on growth performance, carcass characteristics, fatty acid composition and palatability attributes in finishing steers. J. Anim. Sci. 79, 355-365.

Lee, K.N., Kritchevsky, D., Pariza, M.W., 1994. Conjugated linoleic acid and atherosclerosis in rabbits. Atherosclerosis 108, 19-25.

Lee, K.N., Pariza, M.W., Ntambi, J.M., 1998. Conjugated linoleic acid decreases hepatic stearoyl-CoA desaturase mRNA expression. Biochem. Biophys. Res. Commun. 248, 817-821.

Leskanich, C.O., Matthews, K.R., Warkup, C.C., Noble, R.C., Hazzledine, M., 1997. The effect of dietary oil containing (n-3) fatty acids on the fatty acid, physicochemical and organoleptic characteristics of pig meat and fat. J. Anim. Sci. 75, 673-683.

Leyton, J., Drury, P.J., Crawford, M.A., 1987. Differential oxidation of saturated and unsaturated fatty acids in vivo in the rat. Br. J. Nutr. 57, 383-393.

Lorenz, S., Buettner, A., Ender, K., Nürnberg, G., Papstein, H.J., Schieberle, P., Nürnberg, K., 2002. Influence of keeping system on the fatty acid composition in the longissimus muscle of bulls and odorants formed after pressure-cooking. Eur. Food Res. Technol. 214, 112-118.

Madron, M.S., Peterson, D.G., Dwyer, D.A., Corl, B.A., Baumgard, L.H., Beermann, D.H., Baumann, D.E., 2002. Effect of extruded full-fat soybeans on conjugated linoleic acid content of intramuscular, intermuscular and subcutaneous fat in beef steers. J. Anim. Sci. 80, 1135-1143.

Madsen, A., Jakobsen, K., Mortensen, H.P., 1992. Influence of dietary fat on carcass fat quality. A review. Acta Agric. Scand., Sec. A, Anim. Sci. 42, 220-225.

Mandell, I.B., Buchanan-Smith, J.G., Holub, B.J., Campbell, C.P., 1997. Effects of fish meal in beef cattle diets on growth performance, carcass characteristics and fatty acid composition of longissimus muscle. J. Anim. Sci. 75, 910-919.

Marmer, W.N., Maxwell, R.J., Williams, J.E., 1984. Effects of dietary regimen and tissue site on bovine fatty acid profiles. J. Anim. Sci. 59, 109-121.

Matthews, K.R., Homer, D.B., Thies, F., Calder, P.C., 2000. Effect of whole linseed (Linum usitatissimum) in the diet of finishing pigs on growth performance and on the quality and fatty acid composition of various tissues. Br. J. Nutr. 83, 637-643.

Miller, M.F., Schackelford, S.D., Hayden, K.D., Reagan, J.O., 1990. Determination of the alteration in fatty acid profiles, sensory characteristics and carcass traits of swine fed elevated levels of monounsaturated fats in the diet. J. Anim. Sci. 68, 1624-1631.

Mir, Z., Paterson, L.J., Mir, P.S., 2000a. Fatty acid composition and conjugated linoleic acid content of intramuscular fat in crossbred cattle with and without Wagyu genetics fed a barley-based diet. Can. J. Anim. Sci. 80, 195-197.

Mir, Z., Rushfeldt, P.S., Mir, L.J., Paterson, L.J., Weselake, R.J., 2000b. Effect of dietary supplementation with either conjugated linoleic acid (CLA) or linoleic acid rich oil on the CLA content of lamb tissues. Small Ruminant Res. 36, 25-31.

Mohrhauer, H., Holman, R.T., 1963. Effect of linolenic acid upon the metabolism of linoleic acid. J. Nutr. 81, 67-74.

Morgan, C.A., Noble, R.C., Cocchi, M., McCartney, R., 1992. Manipulation of the fatty acid composition of pig meat lipids by dietary means. J. Sci. Food Agric. 58, 357-368.

Nelson, G.J., Ackman, R.G., 1988. Absorption and transport of fat in mammals with emphasis on n-3 polyunsaturated fatty acids. Lipids 23, 1005-1014. 
Nettleton, J.A., 1991. $\omega$-3 fatty acids: comparison of plant and seafood sources in human nutrition. J. Am. Diet. Ass. 91, 331-337.

Nilzen, V., Babol, J., Dutta, P.C., Lundeheim, N., Enfalt, A.-C., Lundstrom, K., 2001. Free-range rearing of pigs with access to pasture grazing- effect on fatty acid composition and lipid oxidation products. Meat Sci. 58, 267-275.

Nürnberg, K., Kracht, W., Nürnberg, G., 1994. Influence of feeding rapecake on carcasse composition and meat quality in pigs. Züchtungskunde 66, 230-241.

Nürnberg, K., Grumbach, S., Papstein, H.-J., Matthes, H.-D., Ender, K., Nürnberg, G., 1996. Fatty acid composition of lamb meat. Fett/Lipid 98, 77-80.

Nürnberg, K., Wegner, J., Ender, K., 1998. Factors influencing fat composition in muscle and adipose tissue of farm animals. Livest. Prod. Sci. 56, 145-156.

Nürnberg, K., Nürnberg, G., Ender, K., Lorenz, S., Winkler, K., Rickert, R., Steinhart, H., 2002. n-3 fatty acids and conjugated linoleic acids of longissimus muscle in beef cattle. Eur. J. Lipid Sci. Technol. 104, 463-471.

O’Quinn, P.R., Nelssen, J.L., Goodband, R.D., Unruh, J.A., Woodworth, J.C., Smith, J.S., Tockach, M.D., 2000. Effects of modified tall oil versus a commercial source of conjugated linoleic acid and increasing levels of modified tall oil on growth performance and carcass characteristics of growing-finishing pigs. J. Anim. Sci. 78, 2359-2368.

Pariza, M.W., Park, Y., Cook, M.E., 2000. Mechanisms of action of conjugated linoleic acid: evidence and speculation. Proc. Soc. Exp. Biol. Med. 223, 8-13.

Pariza, M.W., Park, Y., Cook, M.E., 2001. The biologically active isomers of conjugated linoleic acid. Progr. Lipid Res. 40, 283-298.

Park, Y., Albright, K.J., Storkson, J.M., Liu, W., Cook, M.E., Pariza, M.W., 1999a. Changes in body composition during feeding and withdrawal of dietary conjugated linoleic acid. Lipids 34, 243-248.

Ponnampalam, E.N., Sinclair, A.J., Egan, A.R., Blakeley, S.J., Li, D., Leury, B.J., 2001. Effect of dietary modification of muscle long chain n-3 fatty acid on plasma insulin and lipid metabolites, carcass traits and fat deposition in lambs. J. Anim. Sci. 79, 895-903.

Ponnampalam, E.N., Sinclair, A.J., Hosking, B.J., Egan, A.R., 2002. Effects of dietary lipid type on muscle fatty acid composition, carcass leanness and meat toughness in lambs. J. Anim. Sci. 80, 628-636.

Raes, K., De Smet, S., Demeyer, D., 2001. Effect of double-muscling in Belgian Blue young bulls on the intramuscular fatty acid composition with emphasis on conjugated linoleic acid and polyunsaturated fatty acids. Anim. Sci. 73, 253-260.

Raes, K., Balcaen, A., Claeys, E., De Smet, S., Demeyer, D., 2002. Effect of duration of feeding diets rich in n-3 PUFA to Belgian Blue double-muscled young bulls, on the incorporation of long-chain n-3 and n-6 PUFA in the phospholipids and triglycerides of the longissimus thoracis. In: Proceedings of the 48th ICoMST, vol. II. Rome, Italy, p. 724-725.

Raes, K., Balcaen, A., Dirinck, P., De Winne, A., Claeys, E., Demeyer, D., De Smet, S., 2003a. Meat quality, fatty acid composition and flavour analysis of Belgian retail beef. Meat Sci. 65, 1237-1246.

Raes, K., De Smet, S., Balcaen, A., Claeys, E., Demeyer, D., 2003b. Effect of diets rich in n-3 polyunsaturated fatty acids on muscle lipids and fatty acids in Belgian Blue double-muscled young bulls. Reprod. Nutr. Dev., in press.

Raes, K., Fievez, V., Chow, T.T., Ansorena, D., Demeyer, D., De Smet, S., 2003c. Effect of diet and dietary fatty acids on the transformation and incorporation of $\mathrm{C} 18$ fatty acids in double-muscled Belgian Blue young bulls. J. Sci. Agric. Food Chem., (submitted).

Raes, K., Haak, L., Balcaen, A., Claeys, E., Demeyer, D., De Smet, S., 2004. Effect of linseed feeding at similar linoleic acid levels on the fatty acid composition of double-muscled Belgian Blue young bulls. Meat Sci. 66, 307-315.

Ramsay, T.B., Evock-Clover, C.M., Steele, N.C., Azain, M.J., 2001. Dietary conjugated linoleic acid alters fatty acid composition of pig skeletal muscle and fat. J. Anim. Sci. 79, 2152-2161.

Reeves, J.B., Weihrauch, J.L., 1979. Composition of foods: fat and oils—raw, processed, prepared. US Department of Agriculture, Agriculture Handbook no. 8-4, Washington, DC.

Rey, A.I., Kerry, J.P., Lynch, P.B., López-Bote, C.J., Buckley, D.J., Morrissey, P.A., 2001. Effect of dietary oils and $\alpha$-tocopheryl acetate supplementation on lipid (TBARS) and cholesterol oxidation in cooked pork. J. Anim. Sci. 79, 1201-1208. 
Riley, P.A., Enser, M., Nute, G.R., Wood, J.D., 2000. Effects of dietary linseed on nutritional value and other quality aspects of pig muscle and adipose tissue. Anim. Sci. 71, 483-500.

Roche, H.M., Noone, E., Nugent, A., Gibney, M.J., 2001. Conjugated linoleic acid: a novel therapeutic nutrient? Nutr. Res. Rev. 14, 173-187.

Romans, J.R., Johnson, R.C., Wulf, D.M., Libal, G.W., Costello, W.J., 1995a. Effects of ground flaxseed in swine diets on pig performance and on physical and sensory characteristics of $\varpi-3$ fatty acid content of pork. Part I. Dietary level of flaxseed. J. Anim. Sci. 73, 1982-1986.

Romans, J.R., Wulf, D.M., Johnson, R.C., Libal, G.W., Costello, W.J., 1995b. Effects of ground flaxseed in swine diets on pig performance and on physical and sensory characteristics of $\varpi-3$ fatty acid content of pork. Part II. Duration of $15 \%$ dietary flaxseed. J. Anim. Sci. 73, 1987-1999.

Rule, D.C., Broughton, K.S., Shellito, S.M., Maiorano, G., 2002. Comparison of muscle fatty acid profiles and cholesterol concentrations of bison, beef cattle, elk and chicken. J. Anim. Sci. 80, 1202-1211.

Sañudo, C., Enser, M.E., Campo, M.M., Nute, G.R., Maria, G., Sierra, I., Wood, J.D., 2000. Fatty acid composition and sensory characteristics of lamb carcasses from Britain and Spain. Meat Sci. 54, 339-346.

Sargent, J.R., Tacon, A.G.J., 1999. Development of farmed fish: a nutritionally necessary alternative to meat. Proc. Nutr. Soc. 58, 377-383.

Scollan, N.D., Choi, N.J., Kurt, E., Fisher, A.V., Enser, M., Wood, J.D., 2001. Manipulating the fatty acid composition of muscle and adipose tissue in beef cattle. Br. J. Nutr. 85, 115-124.

Scollan, N.D., Cooper, A., Evans, P., Enser, M., Richardson, R.I., Nute, G.R., Fisher, A.V., Wood, J.D., 2002a. Effect of forage legumes on the fatty acid composition of beef and other aspects of meat quality. In: Proceedings of the 48th ICoMST, vol. I. Rome, Italy, pp. 356-357.

Scollan, N.D., Gulati, S., Wood, J.D., Enser, M., 2002b. The effects of including ruminally protected lipid in the diete of Charolais steers on animal performance, carcass quality and the fatty acid composition of longissimus dorsi muscle. In: Proceedings of the BSAS. New York, UK, pp. 9.

Sinclair, A.J., O’Dea, K., 1990. Fats in human diets through history: is the Western diet out of step. In: Wood, J.D., Fisher, A.V. (Eds.), Reducing Fat in Meat Animals. Elsevier, London, UK, pp. 1-47.

Specht-Overholt, S., Romans, J.R., Marchello, M.J., Izard, R.S., Crews, M.G., Simon, D.M., Costello, W.J., Evenson, P.D., 1997. Fatty acid composition of commercially manufactured $\omega-3$ enriched pork products, haddock and mackerel. J. Anim. Sci. 75, 2335-2343.

Sperling, R.I., 1998. The effects of dietary n-3 polyunsaturated fatty acids on neutrophils. Proc. Nutr. Soc. 57, 527-534.

Sprecher, H., Luthria, D.L., Mohammed, B.S., Baykousheva, S.P., 1995. Reevaluation of the pathways for the biosynthesis of polyunsaturated fatty acids. J. Lipid Res. 36, 2471-2477.

Stangl, G.I., Müller, H., Kirchgessner, M., 1999. Conjugated linoleic acid effects on circulating hormones, metabolites and lipoproteins and its proportion in fasting serum and erythrocyte membranes of swine. Eur. J. Nutr. 38, 271-277.

Strzetelski, J., Kowalczyk, J., Osieglowski, S., Stasiniewicz, T., Lipiarska, E., Pustkowiak, H., 2001. Fattening bulls on maize silage and concentrate supplemented with vegetable oils. Anim. Feed Sci. Technol. 10, $259-271$.

Teitelbaum, J.E., Walker, W.A., 2001. Review: the role of $\omega-3$ fatty acids in intestinal inflammation. J. Nutr. Biochem. 12, 21-32.

Thiel-Cooper, R.L., Parrish, F.C., Sparks, J.C., Wiegand, B.R., Ewan, R.C., 2001. Conjugated linoleic acid changes swine performance and carcass composition. J. Anim. Sci. 79, 1821-1828.

Tinoco, J., 1982. Dietary requirements and functions of $\alpha$-linolenic acid in animals. Progr. Lipid Res. 21, 1-45.

Van Oeckel, M.J., Casteels, M., Warnants, N., Boucqué, Ch.V., 1997. $\omega-3$ fatty acids in pig nutrition: implications for zootechnical performances, carcass and fat quality. Arch. Anim. Nutr. 50, 31-42.

Van Vliet, T., Katan, M.V., 1990. Lower ratio of n-3 to n-6 fatty acids in cultured than in wild fish. Am. J. Clin. Nutr. 51, 1-2.

Vipond, J.E., Swift, G., Noble, R.C., Horgan, G., 1993. Effect of clover in the diet of grazed lambs on production and carcass composition. Anim. Sci. 57, 253-261.

Voedingsaanbevelingen voor België, 2000. De Hoge Gezondheidsraad, Ministerie van Sociale zaken, Volksgezondheid en Leefmilieu, Brussel, Belgie, 81 p.

Warnants, N., Van Oeckel, M.J., Boucqué, Ch.V., 1996. Incorporation of dietary polyunsaturated fatty acids in pork tissues and its implications for the quality of the end products. Meat Sci. 44, 125-144. 
Weber, P., Raederstorff, D., 2000. Triglyceride-lowering effect of $\omega$-3 LC-polyunsaturated fatty acids-a review. Nutr. Metab. Cardiovasc. Dis. 10, 28-37.

Weill, P., Schmitt, B., Chesneau, G., Caniel, N., Safraou, F., Legrand, P., 2002. Effect of introducing linseed in livestock diet on blood fatty acid composition of consumers of animal products. Ann. Nutr. Metab. 46, 182-191.

Williams, C.M., 2000. Dietary fatty acids and human health. Ann. Zootechnol. 49, 165-180.

Wood, J.D., Enser, M., Fisher, A.V., Nute, G.R., Richardson, R.I., Sheard, P.R., 1999. Manipulating meat quality and composition. Proc. Nutr. Soc. 58, 363-370.

Yang, A., Lanari, M.C., Brewster, M., Tume, R.K., 2002. Lipid stability and meat colour of beef from pastureand grain-fed catle with or without vitamin E supplement. Meat Sci. 60, 41-50.

Zock, P.L., De Vries, H.M., Katan, M.B., 1994. Impact of myristic acid versus palmitic acid on serumlipid and lipoprotein levels in healthy women and men. Arterioscler. Thromb. 14, 567-575. 